(C)2018, Elsevier. Licensed under the Creative Commons Attribution-NonCommercial-NoDerivatives 4.0 International http://creativecommons.org/about/downloads 


\section{A social semiotics analysis of Islamic State's use of beheadings: images of power, masculinity, spectacle and propaganda.}

Despite their predominant role in terrorist practices, beheadings have not received sufficient theoretical or empirical attention. The aim of this paper is to explore images of executions by employing social semiotics theory and visual analysis and assess their function. Beheadings by the Islamic State will be employed as an example of spectacular violence. Decapitation will be discussed as a theatrical strategy that attempts to legitimise the Islamic State (and its political project) and to impact upon recruitment of new militants: this is achieved not only by causing material damage, but also by triggering more mundane sentiments in young people who may be more inclined to be attracted to extremist discourses.

Key words: spectacle, beheading, violence, performance, semiotics, terrorism

All throughout history, the act of decapitation has exercised contradictory sentiments: a power battle between horror, disgust, fascination, hatred and entertainment. Like other areas that have recently witnessed a revival of 'old ways' -e.g. the return to old healing texts in order to fight microbes and bacteria (Harrison et al. 2015) or 'cupping' trends among Olympic athletes and celebrities- in the past few years some 'criminal justice systems' across the globe saw a resurgence of ancient punitive practices: China has been accused of medieval torture methods by Amnesty (Phillips, 2015) and has recently invited residents in Guangdong to watch 10 people being sentenced to death in a sport stadium (Haas, 2017); in 2014 Saudi Arabia executed 158 people (Agerholm, 2017), whereas in 2016 beheadings in the country reached the highest level in two decades (Associated Press, 2016); in this global landscape, actions by the Islamic State, in particular, its punitive behaviour towards 'infidels' are frequently associated with medieval punishment.

This frequent association is the rationale for this article. The article will focus on the spectacularisation produced by the act of beheading: sentiments like horror, fascination, amusement, along with the idea of carnivalization will constitute the core of this discussion. These 'emotions' have not been selected randomly; to echo Larson's words, heads are truly amazing (Larson, 2014), no wonder they capture our imaginary like no other body part:

there are lots of good physiological reasons why people find heads fascinating and powerful and tempting to remove. The human head is a biological powerhouse and visual delight. It accommodates four of our five senses: sight, smell, hearing and it draws in the air we breathe and delivers the words we speak. As the evolutionary biologist Daniel Lieberman has written, 'almost every particle entering your body, either to nourish you or to provide information about the world enters via your 
head, and almost every activity involves something going on in your head'.

(Larson, 2014: 11)

Traditionally, heads are symbols of reason and power; removing somebody's head, along with its public display delivers a strong message of dominance. In the past few years, the Islamic State has made wide use of this symbolic form of execution, whose message transcends cultural boundaries. As I shall argue in this article, understanding this strategic choice of punishment (and its fascination) can cast some light on the reasons why so many young people, especially western-born, feel attracted to racialization discourses.

At the end of April 2016, Canadian hostage John Risdell was killed by Abu Sayyaf militants (a pro al-Qaeda group) in the Philippines. His severed head was found in a remote island, five hours after the expiry of a ransom deadline. Once again, Westerners were brutally executed by the hands of extremists. Existing discussions regarding extremism and radicalisation found new vigour in various areas: from politics to social media, from the academic arena to diplomacy. However, despite their predominant role in terrorist practices, beheadings (and videos of executions) do not seem to feature frequently in terrorism scholarship. Friis (2015) noted how beheadings and execution videos have neither been subject to extensive empirical study nor received substantial theoretical attention. Traditionally, terrorism research has developed around (but it is not confined to) the axis of cultural/religious radicalisation (with particular focus on Islamic terrorism), the psychology of terrorist behaviours/collective resistance and, more recently, critical studies on terrorism (Pearlstain, 1991; De Mause, 2002; Stern, 2003; Benmelech et al, 2012; Phillips et al, 2014). Beheadings have been absorbed by broader discussions on 'new terrorism' and its greater brutality (Jäckle and Baumann, 2015), but they have not received adequate primary focus.

The concept of religious violence has been inherently connected to radical, extreme practices (Cavanaugh, 2009). Classical approaches to terrorism have discussed and analysed terror in terms of holiness and sacredness, illustrating how religion could provide a justification for extreme practices (Rapoport, 1984; Rapoport and Alexander, 1982; Laqueur, 1977 and Price, 1977). Executions by Islamic State militants show an intention to construct a sacredness of both their action and their so-called state. Juergensmeyer (2003) explored how religion, humiliation, masculinity and violence are entangled in the tapestry of terrorist warfare, where violence and religion frequently come in tandem. Faith and religion are regarded as forces capable of instigating radical behaviour, creating, consequently, a 'different' form of terrorism: Hoffman (2006) considers the different value systems of this 
new form of violence, its ways of justifying and legitimising actions. He argues that religion is the most important component in current terrorist discourses today, effectively rendering religious terrorism one of the most lethal forms of violence. Beheadings play with sacred, religious images that evoke a sense of transcendence and can be understood by everybody independently of an individual's religious beliefs. However, Gunning and Jackson (2011) challenged the idea of 'religious terrorism', arguing that the religious label requires further qualification to enrich our understanding of violence. The authors suggest that it could be beneficial to seek alternative approaches to the investigation of how beliefs and institutional structures interact with political violence.

The notion that religious beliefs motivate fanatics of terror has frequently been discussed in tandem with radicalisation of Muslim youth (particularly, young men). Integration, alienation from both parental culture and culture of the country of birth, along with socialisation towards violence have been of central interest for terrorism studies and youth studies alike (Lynch, 2013; Horgan, 2008; Silke, 2008). It is also possible to locate the issue of youth radicalisation within the axes of history, culture and political engagement. Violent rites of passages have impacted upon our cultural history: not only have they demarcated important points of transition in life (Van Gennep, 1909/2011; and Bosnia et al, 2015), but they have also captured young people's imagination. The sense of belonging that comes with following a particular social or political cause represents another fundamental consideration for a well-rounded discussion on youth radicalisation and attractions to extreme dogmas. In a study on young Muslims living in London, Ryan (2014) noted how religion helps young Muslims to negotiate and navigate their identity within a secular society. In the example of the Islamic State, religion is closely entwined with political causes; consequently, research on young people's engagement with activism can enhance a discussion of Muslim radicalisation. Whereas belief in a cause cannot be associated to the experiences of radicalisation and extremism, it is worth noting that sharing social, religious and/or political beliefs allows young people to establish connections with others, to (re)affirm and shape their identities: this is especially relevant today where a good portion of socialisation takes place via platforms like Twitter and Facebook, which are also used by radical political groups to spread their message. Social media platforms also favour the circulation of pseudo-sacred images, like the ones featuring Islamic State militants executing western prisoners.

In recent years, with the introduction of new methods brought to the fields of criminology and terrorist studies (e.g. computational methods), a need to enhance more traditional scholarship has arisen. Critical terrorism studies emerged in response to what was 
thought to be a simplistic approach to terrorism by orthodox terrorism scholarship (eg. Schmid and Jongman, 1988; Reid, 1997; Silke, 2004; Ranstorp, 2006). Stronger methodological and epistemological rigour led a new research agenda that intends to extend and deepen the study of terrorism and terrorists (Gunning, 2007; Herring, 2008; Toros, 2008; Zulaika, 2008). This body of research has emphasised the need to tackle terrorist practices from a perspective that can integrate more traditional socio-psychological approaches. The use of decapitation as a terrorist strategy, along with the use of social media by both militants and terrorist sympathisers, should be analysed by employing an analytical framework that allows us to explore images of beheadings more rigorously.

Finally, orthodox and unorthodox research presents a valuable theoretical framework to advance the understanding of terrorist practices: discussion on the use of beheadings sits comfortably within the scholarship presented so far. However, I suggest this could be enhanced by exploring practices like beheadings from a more 'mundane' angle, looking at the possible entertainment that may raise from engaging (both passively and actively) with inhumane practices like decapitation, along with their context of consumption: in other words, I propose to explore the element of carnivalesque (especially in popular Western culture), which may impact upon the reception of the Islamic State's cultural production, regardless of their producers' intentions.

\section{Ontology and Methodology}

The aim of this work is to address some of the gaps in the study of beheadings by the Islamic State. The main research objective is to explore the power of images and how these can be understood, not only as a means to advance terrorist politics (triggering military mobilisation and social division), but also as a way to 'impress' and involve potential sympathisers via the spectacularisation of executions.

This work will apply theories of social semiotics (Jewitt, 1997; Jewitt and Oyama, 2001) to its research sample. Furthermore, the analytical structure provided by Kress and Van Leeuwen's multimodal framework and visual analysis techniques (1996) will be adapted to the analysis of five images of Islamic State's executions.

Main research question:

1. What does the use of widely publicised beheadings signify? Sub questions:

2. Is there something mundane in spectacular executions? 
3. What type of interaction is invoked between the action in the image and viewers?

4. Does a close social nearness/distance create a sense of connection in the viewers?

\section{Sample}

For the purpose of this work, a purposive sample has been selected. Informal data from various websites (e.g. Al Jazeera; Guardian; New York Times; BBC News; El Pais; La Repubblica; Libération; Le Monde; Die Welt) ${ }^{1}$ showed that 2014 registered a peak of reported executions. The executions (and some executioners like Jihadi John) selected here received international attention and became extremely familiar to the general public in Europe and North America.

Images of five ( $\mathrm{n}=5)$ executions by the Islamic State in 2014 (Appendix 1).

1. James Foley (19 ${ }^{\text {th }}$ August)

2. Steven Sotloff $\left(2^{\text {nd }}\right.$ September $)$

3. David Haines $\left(13^{\text {th }}\right.$ September $)$

4. Hervé Gourdel $\left(24^{\text {th }}\right.$ September)

5. Alan Henning ( $3^{\text {rd }}$ October)

\section{Selection Criteria}

The five selected images were the top ones that kept appearing across various search engines (Google; Bing; Dogpile; Ecosia). These search engines were selected being some of the most used on the web. Search was conducted in English, French, Spanish, Italian and German using the following keywords: ISIS, ISIL, beheadings, decapitation, decapitazione, décapitation, decapitación, Enthauptung, Ausführung, esecuzione, execution, execution, ejecución, Islamic state, stato islamico, etat islamique, Islamischen Staat, estado islámico. These images are screenshots of execution videos: news/media channels disseminated this visual material and operated their own judgement of what to divulge to the public (therefore the images were partially manipulated). I chose the screenshots (as opposed to full length videos) for this work in terms of online popularity as these would be the most recurrent and

\footnotetext{
1 As I had no access to official/reliable statistics on executions, I cross-checked data from Wikipedia with a wide range of European and American news websites, which reported on execution trends. The main criteria for the selection of these sources was that their reporting was also cross-checked. I also attempted to replicate these values by searching news in different languages. Search in English, Italian, French, German and Spanish news sites confirmed 2014 as a year of high density of executions.
} 
disseminated images, seen by everybody, not only by people who actively searched for them or decided to watch execution videos.

\section{Analytical frameworks: Social Semiotic Theory}

Semiotics is a philosophical approach to the study, use and interpretation of signs and symbols (Kress and Van Leeuwen, 1996; Kress, 2010). A culture's symbolic systems, like images or texts, function as a means of communication: what people do or say can be interpreted through visual or written communication. Jewitt and Oyama (2001: 134) suggest that semiotic systems can be understood as codes that set out rules for connecting signs and meanings. Barthes (1973) explores how people interpret what they see. His key idea is an interpretative process that follows two main stages: denotation encourages people to ask themselves what or who has been depicted in the image; connotation makes people reflect upon what ideas and values are raised by the representation (Barthes, 1973; Van Leeuwen, 2001). Social semiotics induce a reflection on the signifier (the object/quality) and what this signifier means. In this respect, social semiotics theory can offer the fields of criminology and terrorism studies some insights into how to describe, analyse and interpret events or experiences that are not easily accessible for data collection, like terrorist organisations and their actions. For example, in the context of this work, the five images of executions are considered visual resources that are crafted and staged to divulge specific semiotic messages and meanings: in the lack of direct access to Islamic State militants, these images can support scholars in their inference.

Three analytical dimensions have been taken into consideration. These are adapted and based on visual analysis articulated by the multimodal method (Kress and Leeuwen, 1996). Representational meanings are projected by the producers of an image and explore the syntax of images. For example, in the images used in this work, we recognise the man kneeling as the prisoner. Representational meanings can be divided into two groups (Jewitt and Oyama, 2001: 141): narrative representations (participants are connected by actions and vectors) and conceptual patterns (No actions nor vectors connect participants, which are represented as timeless essences). Interactive meanings explore the attitudes viewers have towards the image. Three aspects inform interactive meanings (Jewitt and Van Leeuwen, 1996): distance (subjects in the image bring viewers closer to the visual action and establish direct relationships with them), contact (people inside the picture look directly at viewers), point of view (identification with the scene in terms of eye level between producers and viewers; complicity as eyes of executioners are at the same level as the eyes of the viewers). 
Compositional meanings refer to the way the content of an image is structured (Jewitt and Oyama, 2001: 147): information values suggest that the role of an element in the image depends on its location in relation to the picture (eg. top, bottom, centre); framing looks at the way participants are represented as belonging together (continuity) or being separate (discontinuity); salience suggests that some elements in the picture are more eye-catching than others; modality is the reality value, so how real or surreal an image is.

\section{Analysis}

Before starting the visual analysis, the context of viewing (where the image is and why the viewer is looking at the image) and context of production (how the image was produced and disseminated) should be considered in relation to the activities of the Islamic State.

\section{The Islamic State}

As per December 2015, the Islamic State has about 30,000 fighters from at least 85 countries (Benmelech and Flor, 2016). The origins of the organisation go back to 2002 when Musab al-Zarqawi started to train extremist combatants. These became central actors in the Iraqi insurgency against American occupation, organizing themselves in a group that swore fealty to Al-Qaeda. The group gradually declined, partly due to increased security of both Iraqi and US forces, but found new vigour in 2011, when it started to become involved with the Syrian civil war (Mapping Militant Organizations Project, Stanford University, 2016). Similar to al-Qaeda, the group identifies itself as a Jihadi-Salafist movement, which adheres to extremist and narrowly interpreted readings of the Quran, along with strict doctrinal concepts like 'true' Muslims must associate themselves with other 'true' Muslims only (Bunzel, 2015: 10). In 2014, during an attempt to take over Sunni Iraq, the Islamic State proclaimed the restoration of the caliphate (transnational Islamic empire), effectively attempting to position itself as the successor of the early Islamic caliphate.

Today, the Islamic State is a Salafi militant organization that aims to expand the caliphate: its project is not simply military, but also political, with plans to construct social structures of a 'legitimate', theocratic state. Their choice of name for the organisation is indicative of an intention to create something that resembles nation-statehood: in 2015, leaked documents revealed that Islamic State plans to set up a treasury and an economic program to be self-sufficient, along with various government departments, including a Ministry for education and health (Shiv, 2015). The concept of nation-state implies share of 
common identity and culture (Yuval-Davis, 1997), along with effective governance (Kohli, 2004). In this respect, it is possible to suggest a connection between traditional understandings of nation-state and the notion of theocratic state by the Islamic State: in particular, the organisation uses a linguistic strategy that attempts to construct and reinforce the idea of Muslim Ummah (a community that transcends national boundaries) (Georges, 2015).

The Islamic State has reached high visibility due to its spectacular executions of foreign workers and individuals who do not fit their narrow interpretation of Islam. Unofficial data available on beheadings mark a peak of their use in 2014 and a sharp decline in $2015-2016^{2}$. Foreign fighters also play the role of executioners. Various explanations have been sought to explain the phenomenon of Westerners joining the Islamic State. Benmelech and Flor (2016) found that poor economic conditions did not impact on recruitment of militants: in fact, the number of foreign fighters joining the organisation is positively correlated with a country's GDP. Perhaps this correlation can be interpreted in terms of means to travel to join the organisation.

Knowing what the Islamic State is and does is relevant to the understanding of how the depiction of their actions is perceived. The viewer, in fact, shares this knowledge. In this respect, it is important to understand how their deeds are consumed and how these reach external audiences.

\section{Context of Viewing}

The images of beheading selected for this work were found on the internet, as part of news articles reporting each execution. The images are in the virtual world, where viewers can consume them from the anonymity of their homes. It can be argued that this anonymised context may favour (in some individuals) what I would define as voyeurism of gruesome, violent events. The way viewers experience the consumption of these pictures changes according to the context the images are seen: news, YouTube, pro-terrorism websites, blogs all offer different frames, in which the visual message is confronted and perceived. Images of executions viewed in a journalistic context may constitute an intentional viewing or may be perceived as supporting information to a story. Seeing the image (or video) on YouTube or Dailymotion may imply a more active engagement with the content: key word search or suggestions based on similar viewings imply the fact the viewer actively searched for images

\footnotetext{
2 Data collected from various news websites: Al Jazeera, Guardian, New York Times, BBC News, El Pais, La Repubblica, Libération, Le Monde.
} 
that display a specific content. Sites like YouTube and Dailymotion allow viewers to consume images as spectacle or theatre. If the image of an execution is accessed via proterrorist websites and forums, its consumption and interpretation may be regarded as more political and purposive, fulfilling a guerrilla strategy.

\section{Context of Production}

This context is particularly relevant to an analysis of images of beheadings and discussion on terrorism. This context encourages reflection on the distribution of the image and the intentions/motives for this. It is undeniable that by disseminating images of executions, the Islamic State intends to legitimise its organisation and project its power within the global landscape. The five images considered in this work were released after the execution: particularly, pictures 1,2,3,5 (Appendix 1) are very neat and staged. The main question relates to what the reason for such staging is: these four images are polished and extremely cinematographic. The contrast between the colours of the two actors (black and orange) sits perfectly sat within the colours of the background (the blue of the sky and the light brown of the soil). The scene is surreal, produced, not just to fulfil its function (beheading), but also to send out two messages: the first (most basic) message is a message of threat and demand of recognition to the 'enemies'; the second (more elaborated) message, I should argue in the next section, is a marketing strategy to sell a 'glamorised' type of guerrilla and the recognition that the roles of captors and captives have been turned upside down.

Picture 4 (which was not directly choreographed by the Islamic State, but by an affiliated group) has a more perfunctory function: this is an unpolished screenshot of the execution, aimed at scaring the 'enemies', but not to craft an appealing, fantastic representation of an execution. Picture 4 is demanding, violent and brutal.

Visual Analysis based on Kress and Leeuwen (1996)'s multimodality

\begin{tabular}{|c|c|c|c|c|c|}
\hline & $\begin{array}{l}\text { Number of } \\
\text { participant } \\
\text { s }\end{array}$ & $\begin{array}{l}\text { Representation } \\
\text { al Meaning: } \\
\text { narrative }(\mathrm{N}) \\
\text { or conceptual } \\
(\mathrm{C})\end{array}$ & $\begin{array}{l}\text { Interactive Meaning: } \\
\text { Distance (D); Contact } \\
\text { (C); Point of view (P) }\end{array}$ & $\begin{array}{l}\text { Composition meaning: } \\
\text { Information values (I); } \\
\text { framing }(\mathrm{F}) \text {; salience }(\mathrm{S}) \text {; } \\
\text { modality }(\mathrm{M})\end{array}$ & $\begin{array}{l}\text { Possible } \\
\text { interpretatio } \\
\text { n }\end{array}$ \\
\hline $\begin{array}{l}\text { Pictur } \\
\text { e } 1\end{array}$ & 2 & $\begin{array}{l}\mathbf{N} \\
\text { There is a vector } \\
\text { (the executioner's } \\
\text { hand touches the }\end{array}$ & $\begin{array}{l}\text { D: medium shot; viewer } \\
\text { induced to establish a } \\
\text { social relationship with } \\
\text { subjects in the picture } \\
\text { C: direct contact with }\end{array}$ & $\begin{array}{l}\text { I: centrality: background } \\
\text { emphasises the two bodies } \\
\text { located at the centre of the } \\
\text { image to increase the } \\
\text { viewer's attention. The line }\end{array}$ & $\begin{array}{lr}\text { Staged scene } \\
\text { where the } \\
\text { function of each } \\
\text { actor is clear; } \\
\text { figure of }\end{array}$ \\
\hline
\end{tabular}




\begin{tabular}{|c|c|c|c|c|c|}
\hline & & $\begin{array}{l}\text { prisoner's } \\
\text { shoulder/neck); } \\
\text { the two bodies are } \\
\text { represented as } \\
\text { anticipating the } \\
\text { main action } \\
\text { (beheading): there } \\
\text { is a subtle action } \\
\text { (executioner } \\
\text { points dagger at } \\
\text { the viewer, by } \\
\text { lifting one arm and } \\
\text { leaving his free } \\
\text { arm on the } \\
\text { prisoner). }\end{array}$ & $\begin{array}{l}\text { viewer; the executioner } \\
\text { points dagger towards } \\
\text { the viewer (viewer is } \\
\text { addressed directly), } \\
\text { symbolically demanding } \\
\text { something out of the } \\
\text { viewer. The executioner } \\
\text { also puts his hand on the } \\
\text { prisoner, establishing a } \\
\text { stronger connection } \\
\text { between the viewer and } \\
\text { the prisoner. } \\
\text { P: frontal, slightly low } \\
\text { angle: } \\
\text { experiences increased } \\
\text { identification/involveme } \\
\text { nt with the scene, but it } \\
\text { is also under the power } \\
\text { of the image. }\end{array}$ & $\begin{array}{l}\text { of the horizon seems to } \\
\text { increase attention on the } \\
\text { prisoner's neckline. } \\
\text { F: continuity between the } \\
\text { two actors, achieved via the } \\
\text { executioner's arm resting on } \\
\text { prisoner's shoulder/neck. } \\
\text { This continuity is extended } \\
\text { to the viewer via the } \\
\text { pointing of the dagger. } \\
\text { S: black outfit of } \\
\text { executioner. Ninjas, in } \\
\text { Japanese tradition, signified } \\
\text { a sense of 'invisibility. The } \\
\text { orange attire of prisoner is a } \\
\text { reference to the orange } \\
\text { scrubs of Guantanamo } \\
\text { Bay's prisoners, but it also } \\
\text { has a cinematographic } \\
\text { recognition (tv series } \\
\text { Orange is the New Black). } \\
\text { M: sensory modality } \\
\text { increases the surreal } \\
\text { symbolism of the action } \\
\text { (beheading). Victim is on } \\
\text { his knees while executioner } \\
\text { is standing. Typical gesture } \\
\text { of beheadings reminding of } \\
\text { ancient forms of punishment } \\
\text { (execution) in history and } \\
\text { culture. }\end{array}$ & $\begin{array}{l}\text { executioner } \\
\text { dressed in black } \\
\text { suggests power, } \\
\text { control. Black } \\
\text { attire may } \\
\text { remind } \\
\text { audiences of } \\
\text { early Japanese } \\
\text { drawings of } \\
\text { ninjas: strength, } \\
\text { guerrilla, } \\
\text { mercenary. } \\
\text { Strong } \\
\text { relationship } \\
\text { between viewer } \\
\text { and actors in } \\
\text { image: } \\
\text { involvement in } \\
\text { both terms of } \\
\text { empathy; } \\
\text { dagger pointed } \\
\text { at viewer } \\
\text { increases } \\
\text { involvement: it } \\
\text { can be } \\
\text { interpreted as } \\
\text { threat, but also } \\
\text { as political } \\
\text { strategy to } \\
\text { attract } \\
\text { followers. } \\
\text { Dagger as } \\
\text { symbol of male } \\
\text { virility, } \\
\text { masculinity. } \\
\text { Executioner's } \\
\text { hand prisoner seems } \\
\text { prison } \\
\text { to suggest that } \\
\text { the act of } \\
\text { execution may } \\
\text { be regarded as a } \\
\text { reward (prize) } \\
\text { for joining the } \\
\text { group. }\end{array}$ \\
\hline $\begin{array}{l}\text { Pictur } \\
\text { e } 2\end{array}$ & 2 & $\begin{array}{l}\text { C } \\
\text { No vectors; the } \\
\text { two bodies are } \\
\text { represented as } \\
\text { 'timeless': there is } \\
\text { a subtle action } \\
\text { (executioner } \\
\text { points dagger at } \\
\text { the viewer, by } \\
\text { lifting one arm); } \\
\text { the two bodies are } \\
\text { distributed } \\
\text { systematically: } \\
\text { they are brought } \\
\text { together } \\
\text { imminent by } \\
\text { execution. }\end{array}$ & $\begin{array}{l}\text { D: medium shot; viewer } \\
\text { induced to establish a } \\
\text { social relationship with } \\
\text { subjects in the picture } \\
\text { C: direct contact with } \\
\text { viewer; the executioner } \\
\text { points dagger towards } \\
\text { the viewer (viewer is } \\
\text { addressed directly), } \\
\text { symbolically demanding } \\
\text { something out of the } \\
\text { viewer. } \\
\text { P: frontal angle; viewer } \\
\text { experiences increased } \\
\text { identification/involveme } \\
\text { nt with the scene. }\end{array}$ & $\begin{array}{l}\text { I: centrality: background } \\
\text { emphasises the two bodies } \\
\text { located at the centre of the } \\
\text { image to increase the } \\
\text { viewer's attention. } \\
\text { F: discontinuity between the } \\
\text { two actors, achieved via the } \\
\text { colour contrast of their } \\
\text { outfits and the gap between } \\
\text { the bodies. } \\
\text { S: black outfit of } \\
\text { executioner. Ninjas, in } \\
\text { Japanese tradition, signified } \\
\text { a sense of 'invisibility. The } \\
\text { orange attire of prisoner is a } \\
\text { reference to the orange } \\
\text { scrubs of Guantanamo } \\
\text { Bay's prisoners, but it also } \\
\text { has a cinematographic } \\
\text { recognition (the orange } \\
\text { uniform will be recognised } \\
\text { as an indication of a }\end{array}$ & $\begin{array}{l}\text { Identification } \\
\text { with the } \\
\text { representation } \\
\text { and symbols } \\
\text { projected by the } \\
\text { image. Power } \\
\text { dynamics: } \\
\text { black figure } \\
\text { holds knife in } \\
\text { sign of } \\
\text { demand/threat. } \\
\text { Knife as sign of } \\
\text { masculinity/mal } \\
\text { e virility. Black } \\
\text { outfit evokes } \\
\text { ninja's outfit } \\
\text { and their sense } \\
\text { of power, } \\
\text { physical } \\
\text { strength, } \\
\text { assassination. } \\
\text { Static, iconic }\end{array}$ \\
\hline
\end{tabular}




\begin{tabular}{|c|c|c|c|c|c|}
\hline & & & & $\begin{array}{l}\text { prisoner thanks to TV series } \\
\text { like Orange is the New } \\
\text { Black). } \\
\text { M: sensory modality } \\
\text { increases the surreal } \\
\text { symbolism of the action } \\
\text { (beheading). Victim is on } \\
\text { his knees while executioner } \\
\text { is standing. Typical gesture } \\
\text { of beheadings reminding of } \\
\text { ancient forms of punishment } \\
\text { (execution) in history and } \\
\text { culture. }\end{array}$ & $\begin{array}{l}\text { image: political } \\
\text { message- threat } \\
\text { and attraction to } \\
\text { this pseudo } \\
\text { military life. }\end{array}$ \\
\hline $\begin{array}{l}\text { Pictur } \\
\text { e } 3\end{array}$ & 2 & $\begin{array}{l}\text { C } \\
\text { No vectors; the } \\
\text { two bodies are } \\
\text { represented as } \\
\text { 'timeless': there } \\
\text { are no subtle } \\
\text { actions } \\
\text { (executioner's } \\
\text { arms are } \\
\text { motionless); the } \\
\text { two bodies are } \\
\text { distributed } \\
\text { systematically: } \\
\text { they are brought } \\
\text { together } \\
\text { imminent by } \\
\text { execution, despite } \\
\text { their apparent } \\
\text { distance. The two } \\
\text { figures become } \\
\text { part of an } \\
\text { 'iconographic' } \\
\text { representation of } \\
\text { an execution. }\end{array}$ & $\begin{array}{l}\text { D: medium shot; viewer } \\
\text { induced to establish a } \\
\text { social relationship with } \\
\text { subjects in the picture } \\
\text { C: direct contact with } \\
\text { viewer: viewer's } \\
\text { attention is on the } \\
\text { prisoner, even though } \\
\text { executioner looks } \\
\text { directly at the viewer, } \\
\text { symbolically demanding } \\
\text { establishing power } \\
\text { dynamics. } \\
\text { P: frontal angle; viewer } \\
\text { experiences increased } \\
\text { identification/involveme } \\
\text { nt with the scene. }\end{array}$ & $\begin{array}{l}\text { I: centrality: background } \\
\text { emphasises the two bodies } \\
\text { located at the centre of the } \\
\text { image to increase the } \\
\text { viewer's attention. The line } \\
\text { of the horizon highlights } \\
\text { power dynamics: } \\
\text { executioner /prisoner } \\
\text { F: discontinuity between the } \\
\text { two actors, achieved via the } \\
\text { colour contrast of their } \\
\text { outfits and the gap between } \\
\text { the bodies. } \\
\text { S: black outfit of } \\
\text { executioner. Ninjas, in } \\
\text { Japanese tradition, signified } \\
\text { a sense of 'invisibility. The } \\
\text { orange attire of prisoner is a } \\
\text { reference to the orange } \\
\text { scrubs of Guantanamo } \\
\text { Bay's prisoners, but it also } \\
\text { has a cinematographic } \\
\text { recognition (TV series } \\
\text { Orange is the New Black). } \\
\text { M: sensory modality } \\
\text { increases the surreal } \\
\text { symbolism of the action } \\
\text { (beheading). Victim is on } \\
\text { his knees while executioner } \\
\text { is standing. Typical gesture } \\
\text { of beheadings reminding of } \\
\text { ancient forms of punishment } \\
\text { (execution) in history and } \\
\text { culture. }\end{array}$ & $\begin{array}{l}\text { Less } \\
\text { identification } \\
\text { with the } \\
\text { representation } \\
\text { and symbols in } \\
\text { the image. } \\
\text { Power } \\
\text { dynamics: } \\
\text { distance } \\
\text { between two } \\
\text { bodies signifies } \\
\text { their different } \\
\text { roles and } \\
\text { dynamics of } \\
\text { subordination. } \\
\text { black figure } \\
\text { holds by his } \\
\text { side: no as } \\
\text { strong sense of } \\
\text { demand as in } \\
\text { previous image. } \\
\text { Knife as sign of } \\
\text { masculinity/mal } \\
\text { e virility. Black } \\
\text { outfit evokes } \\
\text { ninja's outfit } \\
\text { and their sense } \\
\text { of power, } \\
\text { physical } \\
\text { strength, } \\
\text { assassination. } \\
\text { Static, iconic } \\
\text { image: political } \\
\text { message- threat } \\
\text { and attraction to } \\
\text { this pseudo } \\
\text { military life. }\end{array}$ \\
\hline $\begin{array}{l}\text { Pictur } \\
\text { e } 4\end{array}$ & 5 & $\begin{array}{l}\mathbf{N} \\
\text { There are vectors } \\
\text { (the executioners } \\
\text { are disposed } \\
\text { around the } \\
\text { prisoner; their } \\
\text { bodies point } \\
\text { towards the } \\
\text { prisoner); each } \\
\text { body is presented } \\
\text { as playing a part in } \\
\text { the main action } \\
\text { (beheading). }\end{array}$ & $\begin{array}{l}\text { D: medium shot; viewer } \\
\text { induced to establish a } \\
\text { social relationship with } \\
\text { subjects in the picture } \\
\text { C: no much contact with } \\
\text { the viewer: executioners } \\
\text { and prisoners look away. } \\
\text { P: frontal angle; viewer } \\
\text { experiences increased } \\
\text { identification/involveme } \\
\text { nt with the scene, } \\
\text { despite the fact actors } \\
\text { looking away. }\end{array}$ & $\begin{array}{l}\text { I: centrality: executioner s } \\
\text { in the background faction as } \\
\text { marginal elements; attention } \\
\text { on the prisoner, located at } \\
\text { the centre of the image: this } \\
\text { stresses the position of the } \\
\text { victim as } \\
\text { hopeless/vulnerable and the } \\
\text { strength of the marginal } \\
\text { elements. } \\
\text { F: continuity among the } \\
\text { actors, achieved via the } \\
\text { colour of their outfits and } \\
\text { the proximity in which they } \\
\text { stand. } \\
\text { S: prisoner's head looking } \\
\text { away. }\end{array}$ & $\begin{array}{l}\text { This image } \\
\text { seems to } \\
\text { suggest strong } \\
\text { differences } \\
\text { between the } \\
\text { west (prisoner) } \\
\text { and east } \\
\text { (executioners): } \\
\text { prisoner kneels, } \\
\text { surrounded by } \\
\text { executioner s. } \\
\text { Dynamics of } \\
\text { subordination: } \\
\text { east wins over } \\
\text { west. Image } \\
\text { suggests threat, } \\
\text { violence, }\end{array}$ \\
\hline
\end{tabular}




\begin{tabular}{|c|c|c|c|c|c|}
\hline & & & & $\begin{array}{l}\text { M: naturalistic modality: } \\
\text { the scene is not as staged as } \\
\text { the other images and gives } \\
\text { viewers an idea of what a } \\
\text { real execution is like (as } \\
\text { opposed to a more } \\
\text { surreal/symbolic/iconograph } \\
\text { ic execution). Victim is on } \\
\text { his knees while executioners } \\
\text { are standing. Typical } \\
\text { gesture of beheadings } \\
\text { reminding of ancient forms } \\
\text { of punishment (execution) } \\
\text { in history and culture. }\end{array}$ & $\begin{array}{l}\text { demand and } \\
\text { power. Political } \\
\text { strategic } \\
\text { message not } \\
\text { strong: } \\
\text { perfunctory to } \\
\text { demand and } \\
\text { execute. } \\
\text { Weapons: } \\
\text { masculinity, } \\
\text { male virility. }\end{array}$ \\
\hline $\begin{array}{l}\text { Pictur } \\
\text { e } 5\end{array}$ & 2 & $\begin{array}{l}\text { N } \\
\text { There are vectors } \\
\text { (the executioner's } \\
\text { hand touches the } \\
\text { prisoner's } \\
\text { shoulder/neck; his } \\
\text { head is slightly } \\
\text { tilted towards the } \\
\text { prisoner); the two } \\
\text { bodies are } \\
\text { represented as } \\
\text { anticipating the } \\
\text { main action } \\
\text { (beheading): there } \\
\text { is a subtle action } \\
\text { (executioner } \\
\text { points dagger at } \\
\text { the viewer, by } \\
\text { lifting one arm and } \\
\text { leaving his free } \\
\text { arm on the } \\
\text { prisoner). }\end{array}$ & $\begin{array}{l}\text { D: medium shot; viewer } \\
\text { induced to establish a } \\
\text { social relationship with } \\
\text { subjects in the picture } \\
\text { C: direct contact with } \\
\text { viewer; the executioner } \\
\text { points dagger towards } \\
\text { the viewer (viewer is } \\
\text { addressed directly), } \\
\text { symbolically demanding } \\
\text { something out of the } \\
\text { viewer. The executioner } \\
\text { also puts his hand on the } \\
\text { prisoner, establishing a } \\
\text { stronger connection } \\
\text { between the viewer and } \\
\text { the prisoner. The head of } \\
\text { the executioner is } \\
\text { slightly tilted to the side } \\
\text { of the prisoner. This } \\
\text { creates stronger empathy } \\
\text { between viewer and } \\
\text { prisoner, establishing in } \\
\text { this way, the power of } \\
\text { the executioner. } \\
\text { P: frontal, slightly high } \\
\text { angle: viewer } \\
\text { experiences increased } \\
\text { identification/involveme } \\
\text { nt with the scene, but } \\
\text { also has power over the } \\
\text { scene (recruitment } \\
\text { purpose?) }\end{array}$ & $\begin{array}{l}\text { I: centrality: background } \\
\text { emphasises the two bodies } \\
\text { located at the centre of the } \\
\text { image to increase the } \\
\text { viewer's attention. The line } \\
\text { of the horizon seems to } \\
\text { increase attention on the } \\
\text { executioner's } \\
\text { neckline/shoulders/head. } \\
\text { F: continuity between the } \\
\text { two actors, achieved via the } \\
\text { executioner's arm resting on } \\
\text { prisoner's shoulder/neck. } \\
\text { This continuity is extended } \\
\text { to the viewer via the } \\
\text { pointing of the dagger. } \\
\text { S: black outfit of } \\
\text { executioner. Ninjas, in } \\
\text { Japanese tradition, signified } \\
\text { a sense of 'invisibility. The } \\
\text { orange attire of prisoner is a } \\
\text { reference to the orange } \\
\text { scrubs of Guantanamo } \\
\text { Bay's prisoners, but it also } \\
\text { has a cinematographic } \\
\text { recognition (TV series } \\
\text { Orange is the New Black). } \\
\text { M: sensory modality } \\
\text { increases the surreal } \\
\text { symbolism of the action } \\
\text { (beheading). Victim is on } \\
\text { his knees while executioner } \\
\text { is standing. Typical gesture } \\
\text { of beheadings reminding of } \\
\text { ancient forms of punishment } \\
\text { (execution) in history and } \\
\text { culture. }\end{array}$ & $\begin{array}{l}\text { Staged scene } \\
\text { suggesting } \\
\text { dynamics } \\
\text { power, control } \\
\text { and threat. } \\
\text { Black attire } \\
\text { reminding of } \\
\text { ninjas: strength, } \\
\text { guerrilla, } \\
\text { mercenary. } \\
\text { Strong } \\
\text { relationship } \\
\text { between viewer } \\
\text { and actors in } \\
\text { image: } \\
\text { involvement in } \\
\text { both terms of } \\
\text { empathy (partly } \\
\text { achieved via the } \\
\text { executioner's } \\
\text { hand on the } \\
\text { prisoner's } \\
\text { shoulder and } \\
\text { the ox } \\
\text { executioner's } \\
\text { head being } \\
\text { tilted to the } \\
\text { prisoner's side); } \\
\text { dagger pointed } \\
\text { at viewer } \\
\text { increases } \\
\text { involvement: } \\
\text { demand, threat, } \\
\text { but also as } \\
\text { political } \\
\text { strategy to } \\
\text { present } \\
\text { surreal image of } \\
\text { IS guerrilla. } \\
\text { Dagger } \\
\text { symbol of male } \\
\text { virility, } \\
\text { masculinity. } \\
\text { Executioner's } \\
\text { hand prisoner seems } \\
\text { prisong suggest that } \\
\text { to act of } \\
\text { the } \\
\text { becution may } \\
\text { (prize) reward } \\
\text { joining ther } \\
\text { group }\end{array}$ \\
\hline
\end{tabular}




\section{Discussion}

Some common elements emerge across the five pictures. The images propose both narrative and conceptual structures: these are enriched by strong symbols, which aim to construct both stories/actions and surreal representations. Pictures 1, 4, 5 construct narrative representations, where the actors in the image impart to viewers the idea that an action is unfolding: in these pictures vectors connect executioners to the prisoner and to the viewers (the militant's arms are stretched towards the prisoner and the viewer). Pictures 2 and 3 portray more conceptual patterns, with the actors in the image not doing anything, but rather as being the 'representation of punishment'. Despite these being screenshots from videos, the images project a sense of 'doing' and movement. Furthermore, three lines of discussion emerge from the visual analysis: 1) the construction of power and masculinity these images attempt to disseminate; 2) the staging of an almost surreal scene of beheading; 3 ) the use of these theatrics as a political message. To demonstrate the visual power of terrorist theatrics, I have associated the screenshots to a wide range of images, coming from visual arts. These images come from popular culture, paintings, medieval marginalia and propaganda posters. They also come from different historical periods and geographical locations. The point I intend to raise with this association is that the Islamic State (unintentionally or intentionally) choreographs its executions in a manner that is recognisable and in line with what has been historically and transnationally associated to the idea of executions and recruitment.

\section{Beheadings, power and masculinity.}

Common traits that accumulate across the five pictures are the dynamics between executioners and prisoners, with the former standing next to or behind the latter, and the use of weapons. Salience in composition meaning in pictures 1,2,3,5 demonstrates the contrast between the black outfit of the executioner and the orange uniform of the prisoner: the focus is on the executioner. Other than their connection to the organisation's flag, the black attire worn by Islamic State militants may (unintendedly) remind young Western audiences of shinobi (ninja) culture from medieval Japan (Pictures B, C, Appendix 2). Ninjas appear frequently in popular culture: films, video games, TV-shows and animation can feature a fantasised depiction of ninjas warriors. The image of the ninja may be decoded in different ways, depending on cultural variables, but it is potentially recognisable at a global level. Furthermore, Ninjas have always been associated with assassination, mercenary and clandestine warfare, along with espionage: Japanese medieval chronicles described shinobi as 
kancho (spies), teisatsu (scouts), kisho (surprise attackers), and koran (agitators) (Turnbull, 2003: 9), attributes that can also be used to describe Islamic State militants. According to Turnbull (2003), the earliest visual reference to a ninja dressed in black goes back to 1801: the choice of black clothing refers to the sense of being invisible and, in this way, effective in clandestine combat. For Islamic State militants, the black outfit also echoes the black standard, traditionally associated to one of the flags flown by Muhammad. Black carries the sense of tradition, along with warfare.

The popularisation and myths of ninjas mean that the semiotics of their attires are cross-border and transnational, being recognisable to both eastern and western audiences. The body of the (unintended) ninja/Islamic soldier becomes a vehicle of meanings. It carries the sense of hegemonic masculinity, power and subversion. The static, iconic images of executions (Pictures 1,2,3,5) convey the message that the Islamic State 'solider' is an invincible power that can attack any time. Masculinity and power are reinforced by the staging of the execution and the images' conceptual patterns: pictures 2 and 3 show discontinuity between the two actors, allowing viewers to focus their attention on the blackclad figure and the symbolic message he attempts to divulge.

The framing in the compositional meaning of pictures 1 and 5 displays continuity between the two participants in the image: this is achieved via the executioner's arm resting on the prisoner's back/shoulder. Continuity is also extended to viewers via the pointing of the dagger towards the camera. The composition hints that the entities inside the picture (executioner and prisoner) and outside the picture (viewers) belong together. This creates power dynamics among all entities involved: the executioner keeps the image together, establishing, in this way, his dominance over victim and viewer. Traditionally, the figure of executioner has been conceived as playing a role in divine justice (De Maistre, 1821; Potter, 1993). The iconography of Islamic State executions seems to emphasise dynamics of subordination between victim and perpetrators (the west kneeling down to the east): picture 4 is particularly effective at demonstrating this. The victim is powerless in a scene that is rough and graphic (naturalistic modality). Furthermore, in pictures 1,2,3,5 victims do not show emotions: this makes viewers less likely to identify themselves with the victim, leading to a stronger focus on the symbolic act of beheading and its perpetrator. Viewers are encouraged to connect with the militant and the image of power and masculinity he intends to set out. It could be argued that the message that comes from this is an abstract political concept rather than a personal story between two actors. Picture 4 differs from this: emotions on the victim's face are more perceivable, allowing viewers to connect with him. 
Power and subordination dynamics are also reinforced by the fact that executioners carry weapons. A dagger is visible in pictures 1,2,3,5, whereas a Kalashnikov stands out in picture 4. Weapons are symbolic of masculinity and male virility. The use of daggers and other weapons are not just a way to assert power or purposive for the aims of the beheading, but they are also an enactment of hegemonic masculinity (Connell, 2005). Propaganda posters from World War I and World War II (Pictures D, E, G) played of this sense of masculine power, showing images of soldiers carrying weapons. Drawing on a wide range of studies, Page (2009) suggests a strong relationship between weapons, power and masculinity, emphasising how this link emerges from a complex knit of multiple social factors, along with perception and glamorisation of weapons. Visual analysis of beheadings seems to confirm this symbolic use to assert a normative ideal of power.

\section{Theatrics in terrorist executions.}

A salient aspect that emerges from semiotic analysis of the pictures is that sense of staged, crafted spectacle. Specifically, analysis attached to the composition meaning brings to the surface a narrative that shifts to a surreal, conceptual symbolism.

Kepel (2004) suggests that, from an Islamic perspective, beheadings represent the most traditional capital execution: religious texts describe stories of Muslims cutting the heads of their enemies. In this respect, the decapitation staged in pictures 1,2,3,5 aims to visually affirm this tradition. When confronted with images of executions, the skills involved with beheading should be also considered: cutting through tissues and bones is not an easy exercise. Larson (2014: 89) highlights the unpredictability of beheading, emphasising how removing somebody's head with a knife or an axe in a single clean motion (while the person is still alive) requires a lot of strength, skill and luck. In this respect, beheading as a terrorist strategy is effective only in terms of theatricality, rather than an effective way of killing the enemy.

The power of image is an important aspect when attempting to understand the use of beheadings by the Islamic State. The visual impact of the imminent executions in pictures 1 and 5 is very strong mainly because of the vectors that link executioner, prisoner and viewers. This creates a bond, a relationship between actors in the pictures and viewers. The viewer is struck by the composure and solemnity of the act: Islamic State militants attempt to project a pseudo rituality to legitimize their action. Executions follow the same visual procedure: the Islamic State militant, dressed in black, is behind the victim, dressed in orange scrubs (pictures 1,2,35). The militant's body emanates a sense of threat towards the perceived 
enemy (the West, the infidels), holding a knife. The victim is subdued (however, composed) and involuntarily plays a part in this spectacle. This is visible in the surreality of pictures 1,2,3,5 (carefully composed, designed to be spectacular and impress) and in the perfunctoriness of picture 4. This may reinforce the fact that the Islamic State (as a political project) is more based on the power of visuals and the staging of attacks, rather than relying on more established military or political routes.

Drawing on Austin and Butlers' concept of performativity and Goffman's dramaturgical model, I suggest beheadings represent the enactment of performativity of spectacular violence. I should clarify how I use the idea of performativity outside its linguistics and philosophical location. The concept of 'performative' permits to move beyond the description of an experience, but rather engagement with it. Butler (1997) suggests that performances reinforce and divulge people's identity in society. Austin (1962) describes how words allow the construction of events and actively shape people's performances. The dramaturgical perspective (Goffman, 1990) encourages us to look at people's identity and social interactions as roles performed on stage. Therefore, human social behaviour is scripted according to the roles taken on by actors. Each performance is an attempt to construct specific impressions and present idealised views of a situation.

With this theoretical framework, I propose to look at beheadings as a performance, that becomes legitimised (in the eyes of the organization) via repetition and self-citation: the scenes portrayed in pictures 1,2,3,5 have become an iconography of terrorist subculture and, to a certain extent, they are divulged and reproduced in popular culture and satire (see Picture A in Appendix 2). Islamic State's use of orange uniforms for its prisoners is a symbolic representation of the essence of a prisoner, with the orange scrubs reminding viewers of both Guantanamo Bay's inmates and popular TV shows like Orange is the New Black. Like for the black attire, the globalisation of popular culture allows people from different cultural backgrounds to identify what the orange uniform stands for. Picture 4 differs from this pattern: the image is presented in naturalistic modality (as opposed to the sensory modality of pictures 1,2,3,5), giving viewers a more robust taste of what an execution entails. Pictures of beheadings like pictures 4 do not seem to have captured people's imaginary as much as images of the orange-clad prisoner. In fact, when performing an image search of executions via engines like Google, the performative of executions featuring black and orange figures is the most predominant.

Performance theory draws attention to the performative nature of societies and how rituals and daily behaviours are governed by an implicit code of performance. The difference 
in modality of the five pictures emphasises just that. From a performance theory perspective, individuals elaborate their own performative trajectory in life, making society a product of performance. Goffman suggests:

\begin{abstract}
When an individual plays a part he implicitly requests his observers to take seriously the impression that is fostered before them. They are asked to believe that the character they see actually possesses the attributes he appears to possess, that the task he performs will have the consequences that are implicitly claimed for it, and that, in general, matters are what they appear to be (Goffman, 1969:17)
\end{abstract}

Islamic State militants employ performative violence to reinforce both their individual and collective identities. The role of ritualistic violence performed by the Islamic State is, consequently, to shape its community from the inside and in the eyes of the world. Executions aim to make the Islamic State more robust than a virtual state via the use of performative punishment.

The use of spectacular punishments and violence to establish and legitimise power is not a new experience. Uses of terror and corporal punishment for the means of social control have been a feature in humankind's history. Cavarero (2011: 2) suggests that "the words terrorism and war evoke concepts from the past and muddle them rather than give them fresh relevance". In medieval times, executions were carried in front of a half alarmed, half excited crowd. The slaying of criminals went beyond its punitive aim, but had the dual function of entertaining and deterring people from disobeying. Nowadays the stage of spectacular punishments has moved from a physical arena to a virtual space (eg. youtube): due to its ancient origin, the Islamic State has revived this 'out-dated ${ }^{3}$ form of punishment, relying, as I mentioned, on its visual effectiveness.

As anticipated at the beginning of this work, we are witnessing a revival of medieval attitudes in our society: on $22^{\text {nd }}$ July 2011, Norwegian citizen Anders Breivik set off a car bomb in front of the office of the Prime Minister and other government buildings in Oslo. The causalities amounted to 8 deaths and over 200 wounded. Later Breivik attacked a summer camp on the island of Utøya, killing 69 people and wounding 110. This was the deadliest attack in Norway since the Second World War. Breivik described himself as a member of a neo-medieval, underground paramilitary group known as the Knights Templar. In this respect, I suggest that the Islamic State may rely on the power and familiarity that

\footnotetext{
${ }^{3}$ Deliberately outdated as the Islamic State rejects modernity and intends to recreate golden age of Islam.
} 
'fictional medieval narratives' exercise on young people (which I refer to as 'the Game of Thrones generation") thanks to fantasy TV shows, films and video games.

There are many examples all throughout history that display the seduction violence exercises on people, particularly the seduction that executions instigate. As mentioned earlier, cutting off somebody's head delivers a strong message of power because heads are the centre of people's senses. Furthermore, the semiotics of beheadings encourage a wider reflection: in all pictures victims are on their knees (traditionally, kneeling and bowing have been regarded as a gesture of surrender or of humiliation), executioners stand tall (symbol of power), executions receive centre stage and prisoners do not seem to display fear (perhaps, the function of an unperturbed victim is to legitimise the power of the executioner). Yet, victims are submissive/passive, emphasising the power of the executioner. Larson (2014) points out that in medieval and modern Europe, decapitation was an honourable way to die. In relation to the Islamic State, I suggest that this act may be carried because, in the eyes of militants, it also dignifies executioners, legitimising the strength of their organisation. It delivers the message of surrender and power (eg. the Islamic State) at the centre of the virtual square (i.e. global landscape).

In this work, I have connected beheadings to images that are similar to the ones medieval people would have recognised. The connection between beheadings and middle ages helps create assumptions regarding the more mundane sentiments (e.g. thrill, entertainment, excitement) that executions may trigger in some individuals. Bakhtin (1984) theorises people's fascination with spectacular punishment by suggesting that medieval people lived two lives: an official one that was subjugated to strict orders and behavioural codes; and a second life that occurred in the carnival square (during the period of the carnival). This was a grotesque experience, characterised by satire, collective ridicule, laughter, violations of decorum and subversion of values. The sense of mockery and amusement that accompanied beheadings was also concretised in visual representations: picture $\mathrm{F}$ shows a marginalis that adorned medieval manuscripts. It represents beheadings by sword, where the executioner is a rabbit, symbol of fertility/prosperity that is turned upsidedown and becomes 'dangerous', evil. Other marginalia featured fantastic creatures and/or apes beheading people: medieval audiences would have recognised these images as symbols of demons, but would have also found them exciting and entertaining.

These same dynamics are visible in the executions of the Islamic State, where the terrorist narrative is embroidered by performance, glamorisation of the guerrilla and threat. Pictures 1,2,3,5 show an attempt to divulge strict pseudo religious dogmas: sensorial 
modality and salience create an iconography of execution, that is theatrical and involves viewers in the scene. The images are not repellent, but almost polished (therefore more suitable for mass dissemination). Picture 4, through its naturalistic modality, gives viewers a sense of the grotesque: the prisoner looks away, the image is not polished, but viewers are drawn to it. Therefore, it is possible to establish some connections between the images of beheadings disseminated by the Islamic State and the functions that executions had in the past. However, a main difference is visible: the grotesque elements that are identified with the carnival period are not, in the case of Islamic State executions, restricted to a specific moment. On the contrary, they are ongoing, continuous and can occur at any time. Yet, the analogy between Islamic State executions and the carnival is justified in the sense that the component of entertainment visible in the carnival is also present in today's executions. Beheadings are televised, divulged and glamorised, partly, as I will argue in the following section, for political propaganda, partly for recruitment purposes.

\section{Beheadings as Political performance}

Emerging from the analysis is this idea of theatrics and spectacle that have a multifunctional aim: displaying dynamics of power and masculinity and entertainment/attraction like in medieval times. However, analysis of the interactive meaning brings to the surface an extra layer. The social nearness (distance between viewers and what is represented in the images) in all pictures is medium shot. This induces viewers to establish a relationship with the subjects in the image (Jewitt and Oyama, 2001). There is direct contact with the viewer and the point of view of the image consists of a frontal angle, which also encourages viewers to be involved with the scene. Pictures 1,2,3,5 (to a lesser extent, picture 4) support an increased identification between viewer and action. The combination of viewers' involvement and a staged composition of the execution raise questions regarding the further motivations for such a theatrical beheading. It could be argued that specular executions have the goal to legitimise the terrorist cause, but they also glamorise war for recruitment. The audience targeted by the Islamic State is particularly receptive to the glamorisation of executions: on one hand, executions are choreographed to appeal to the 'Games of Thrones generation where fantasy reconstructs surreal, polished executions. On the other hand, the theatrics of beheadings ensure that enemies are terrorised and repelled.

Throughout history, young people have been fascinated by the idea of making war and fighting for a cause, like in the case of World War I, when joining the front represented 
for many an opportunity to leave home, go abroad and reach manhood. Agamben (2008) suggested that through rituals, a society (e.g. Islamic State) decides who is sacred and who is not. With the ritualistic, spectacular violence of beheadings (and their ritualised repetitions), the Islamic State attempts to legitimise its role as a State: the organisation has created a visual format that is iconographic and purposive. Agamben defines as homo sacer a life that can be killed, but not sacrificed. Victims of decapitations are a specific type of homo sacer: Agamben (2008) argues that homo sacer are politically irrelevant, but in the case of Islamic State, they are relevant because they reaffirm their militancy.

Nick Berg was executed in Iraq in May 2004. Reuters released an unedited video of his execution, whose shorter clips were later reposted by major news channels across the world. Newspapers reported opinions of medical experts who saw the video: these reports were extremely meticulous in their description of the scene, raising the question of whether such a high level of details was indeed necessary. The shift from broadcast to social media means that images are shared much faster than they used to be, increasing people's terrorist voyeurism and making terrorism almost instantaneous. Bakhtin's carnival square has become virtual and spatial, enacting an ongoing satire: this virtual carnival allows the consumption of beheadings from the safe space of our homes, turning beheadings into a virtual political performance. For Kepel, beheadings are powerful in the sense that they create a morbid fascination, especially among young people, for whom the lines between cinematographic violence and reality are blurred (Kepel, 2004). Picart (2007) discusses the emergence of a gothic criminology to discuss people's infatuation with what is gruesome, evil and bloody. In this respect, the performance of beheading has much more effect than other terrorist performances (eg. suicide bombings), not only for its low costs, but also because people consuming the scene from home can identify themselves with either the body whose head has been cut off (Kepel, 2004) or, I suggest, with the executioner. Harrow (2011) suggests decapitation is a strategy that has maximum visibility, resonance and implants maximum fear. The victim becomes an instrument in the staging of a terrorist carnival and in the implementation of theatrical pseudo-military tactics. Analysis of the interactive meanings in the semiotics of beheading seems to support this: particularly, pictures 1 and 5 achieve that thanks to the continuity among viewer, executioner and victim. These two pictures seem to echo propaganda posters like those in pictures D, E, H and G (appendix 2). The dagger is pointed at the viewer in the gesture of symbolically demanding something and threatening ('it could be you here!'), but also attracting the viewer from outside the image to the inside: 'have you volunteered yet?' (picture E); 'what are you waiting for?' (picture D). 
The high rate of young people born in the West joining the cause of Islamic State raises the question on how this 'violent performative' impacts on recruitment. Based on visual analysis, I believe two perspectives should be considered: violence as theatrical 'pseudo' military tactics and the importance of visual/social media in contemporary warfare and its legitimisation.

The 9/11 attacks marked a new era for terrorism as images of the attack were divulged almost in real time across the globe. The images of planes hitting the Twin Towers and the bodies falling from the windows were similar to the images we saw in apocalyptic films. The attacks were not simply political statements, but seemed to be carefully crafted for mass consumption. Cowen (2006) regards terrorism as a spectacle produced for viewers: drawing on Sorel's work on violence, where it is argued that dictatorships stage public executions so that citizens have a memorable visual story (Sorel, 1999), Cowen (2006) suggests terrorist organisations reproduce a similar narrative: staging of spectacular terrorist behaviours can motivate and aid fundraising for subsequent terrorists. In this respect, I refer to beheadings as theatrical tactics, because their goal is not just the alienation of the enemy, but also the projection of a narrative that attracts new recruits. The fascination and, in a way, the glamorisation that executions trigger in individuals constitute the most dangerous aspect of the Islamic State. Finding a way to engage with that may impact on future policies and lawenforcement strategies.

The theatrical tactics employed by the Islamic State to legitimise and publicise their cause are also part of a broader discussion on the importance of visual media in contemporary warfare. Most scholarship on the use of video by terrorist organisations has focused on its power of divulging fear or as means of propaganda (Friis, 2015). In line with that, I suggest that the propagandistic side should be explored more thoroughly. Islamic State's warfare is peculiar because it relies on the pictures of attacks and executions. Without the resonance these images receive, via platforms like YouTube and/or other social media, recruitment and the survival of the organisation would be effected. Images are the main ammunitions used in this pseudo warfare.

\section{Limitations of the social semiotic approach}

Social semiotics and the techniques involved with multimodal analysis have been selected and adapted as the most appropriate methods of investigation because they are based on the idea of layered meaning and layered interpretation of images. They emphasise a relationship among signs, signifiers, objects and those who interpret them (Eco, 1975). This 
provides researchers with a structure in which to locate their analysis. However, this form of analysis is subject to limitations and drawbacks.

While the analysis performed in this work follows structured parameters, it is nonetheless subject to a strong interpretative component. Rastier (1998: 222) suggests that even when attempting to create a general category of interpretation, we still employ our own typology of standards, modes and interpretative regimes. In other words, we, as researchers, apply an interpretative principle to the parameters we aim to assess. Similar to other qualitative approaches, a pure, scientific neutrality is beyond the reach of the semiotics method. In the analysis presented here, I attempted to suggest patterns and signs that could be considered transnational and cross-cultural. Different audiences would have a different positionality: images may be recognisable, but not decoded in the same way. Furthermore, my selection was informed by my cultural identity and my research expertise. Another limitation of this approach is that social semiotics and multimodal analysis may be time consuming, too technical and laborious: the same image or video should be assessed several times and from different interpretative perspectives and meta-functions. When the sample is large, this may cause errors and inaccuracies.

Social semiotics is not, therefore, infallible. However, its contribution is that it presents an analytical framework that allows us to make sense of experiences and populations that are beyond our reach with other methods. This type of investigative approach offers us a way to explore what we may somehow understand at an intuitive level, but have no other systematic manner to test.

\section{Concluding thoughts: implications for addressing the iconography of terrorist subculture.}

Images of Islamic State militants arranging heads of their decapitated victims have also been divulged via media: again, an analogy with medieval times can be found. In fact, the arranging of severed heads evokes the way medieval people used to dig out corpses and remove their heads, so that they were sure bodies were dead. It was an ultimate reassurance that no resurrection would occur. In the beheadings by the Islamic State the same symbolism can be perceived: images spread the message that the infidel will not resurrect. Terrorist executions revive old images which are nonetheless cross-border and transnational. The deeds committed by Islamic State militants bring to surface two main implications for the way 'their' violence is articulated: violence as a strategic, spectacular consumption and the use of violence as a means to instigate what I call terrorist voyeurism (the compulsive 
fascination with seeing images of executions). Žižek (2009) discusses people's reaction to terrorism in terms of subjective violence. This violence is conducted by a clearly identifiable agent and creates an immediate physical, physiological reaction. Beheadings are also a subjective type of violence: they trigger penal voyeurism, they instigate a reaction and create a theatre that both legitimise the Islamic State as a political project and attract young people who are used to cinematographic executions. Viewers are pulled into the image and are more receptive to the message. A sense of complicity is established between militant and viewer.

Drawing on Žižek's work I suggest that the subjectivity of beheadings is visually crafted in such a way that people expect a quick counter-response: a military mobilisation, social division, but, for some individuals, involvement. In the aftermath of terrorist executions, the theatrics of beheadings call for a collective response: civil society wishes to see a counter-attack, whereas terrorist sympathisers would wish to partake in the images of victory (eg. beheadings). These actions/reactions, infused with morbid fascination, spectacle and solemnity, can play a part in recruitment. The use of televised executions is this: the sensory modality of beheadings creates a 'romanticised' vision of terrorist warfare. In people who are more prone to succumb to extremist discourses, this may trigger enthusiasm for doing violence and may constitute one of the motivations for young westerners to join Islamic State militancy. Today like in the past, rituals and images enhance and legitimise dogmas and beliefs. Nowadays, however, engagement with rituals and images has changed in terms of global mobility and intersection of various occurrences (e.g. religion, films, video games, social media, politics).

From visual analysis, it seems apparent that images of beheadings aim to create a close social nearness/distance between viewers and actors in the image. This may impact upon recruitment due to the staging of a fantasy warfare and a glamorised morbid narrative that the terrorist organisation attempts to tell. The true brutality of guerrilla is not 'publicised' to the same extent of these surreal images because, strategically, it does not serve the purpose of mobilisation as well as crafted images.

Deglamourizing something that has been put together with the goal to create an iconographic narrative is perhaps the challenge of policy-makers and counter-terrorism strategies. In this respect, France may be a step closer to achieve that: in an editorial in French newspaper Le Monde, Fenoglio (2016) called for French media to stop publishing photos and names of Jihadists to avoid posthumous glorification. If this approach had to be adopted by all mass and social media across the globe, terrorist spectacular strategies would lose part of their strength. 
Finally, taking the study of terrorist organisations and subcultures forward, a more 'mundane' discussion should walk side to side with traditional, orthodox approaches to terrorism and radicalization. In a world of professional insecurity, political instability and social isolation, the power of images and constructed representation via social media cannot be omitted by criminological discourses on extreme, pseudo political/religious practices. 


\section{Bibliography}

Agamben, G. (2008) Homo sacer. Il potere sovrano e la nuda vita. Turin: Einaudi

Agerholm, H. (2017) 'Outcry as Saudi Arabia executes six people in one day to bring 2017 death penalty total to 44'. The Independent, $11^{\text {th }}$ July 2017.

Associated Press (2016) 'Saudi Arabia: beheadings reach highest level in two decades'. The Guardian, $2^{\text {nd }}$ January 2016.

Austin, J. L. (1962): How to Do Things With Words, Oxford: The Clarendon Press.

Bakhtin, M. (1984). Rabelais and his world. Bloomington: Indiana University Press.

Barthes, R. (1973) Mythologies. London: Paladin.

Benmelech, E. and Klor, E. (2016) 'What Explains the Flow of Foreign Fighters to ISIS?'. National Bureau of Economic Research Working Paper 22190.

Benmelech, E. Berrebi, C. and Klor, E. (2012) 'Economic conditions and the quality of suicide terrorism' The Journal of Politics, 74(1), 113-128

Bosnia, A.N. Griessenauer, C.J. Haddad, V. and Shane, T.R. (2015) 'Ritualistic Envenomation by Bullet Ants among the Sateré-Mawé Indians in the Brazilian Amazon'. Wilderness and Environmental Medicine, 26(2), pp.271-273.

Bunzel, C. (2015) 'From paper state to Caliphate: the ideology of the Islamic State'.

Butler, J. (1997). Excitable speech: a politics of the performative. New York: Routledge

Cavanaugh, W., 2009. The myth of religious violence. Oxford: Oxford University Press.

Connell, R. (2005). Masculinities. Cambridge: Polity.

Cowen, T. (2006). Terrorism as theater: Analysis and policy implications. Public Choice, 128(1), 233-244.

De Maistre, J. (1821) The executioner. Penguin Classics (ed. 2009).

De Mause, L. (2002). 'The childhood origins of terrorism'. Journal of Psychohistory 29, $340-8$.

Eco, U. (1975) Trattato di semiotica generale. Milan: Bonpianti.

Fenoglio, J. (2016) 'Résister à la stratégie de la haine'. Le Monde, 27th July 2016. Posted at: http://www.lemonde.fr/idees/article/2016/07/27/resister-a-la-strategie-de-lahaine_4975150_3232.html 
Friis, S. (2015). 'Beyond anything we have ever seen': Beheading videos and the visibility of violence in the war against ISIS. International Affairs, 91(4), 725-746.

Georges, A. (2015) ISIS Rhetoric for the creation of the Ummah. TRENDS Research and Advisory.

Goffman, E. (1990). The presentation of self in everyday life. London: Penguin.

Gunning, J. (2007). Hamas in Politics: Democracy, Religion, Violence. London: Hurst.

Gunning, J. and Jackson, R. (2011) 'What's so 'religious' about 'religious terrorism'?'. Critical Studies on Terrorism Vol. 4, No. 3, 369-388

Harrison, F., Roberts, A., Rumbaugh, K., Lee, C. and Diggle, S. (2015). 'A 1000-year-old antimicrobial remedy with anti-Staphylococcal activity' $m$ Bio. $6(3)$.

Harrow, M. (2011) 'Video recorded decapitations- a seemingly perfect terrorist tactic that did not spread'. Danish Institute for International Studies, working paper 08.

Haas, B. (2017) 'Thousands in China watch as 10 people sentenced to death in sport stadium'. The Guardian, $18^{\text {th }}$ December 2017.

Herring, E. (2008) 'Critical Terrorism Studies: An Activist Scholar Perspective' Critical Studies on Terrorism, 1(2): 197-212.

Hoffman, B. (2006). Inside terrorism. New York: Columbia University Press.

Horgan, J. (2008) 'From Profiles to Pathways and Roots to Routes: Perspectives from Psychology on Radicalization into Terrorism.' ANNALS, American Association of Political and Social Sciences 618 (July): 80-94

Jäckle, S. and Baumann, M. (2015). "New terrorism" = higher brutality? An empirical test of the "brutalization thesis". Terrorism and Political Violence, 1-27.

Jewitt, C. (1997) 'Images of men', Sociological Research Online, 2(2).

Jewitt, C. and Oyama, 'Visual Meaning: a semiotic approach' in Van Leeuwen, T. and Jewitt, C. (2001). The Handbook of Visual Analysis. London: Sage Publications.

Juergensmeyer, M. (2003) Terror in the mind of God: the global rise of religious violence. Berkeley: University of California Press.

Kepel, G. (2004), 'Escenificación de la muerte' El País, 24th September.

Kohli, A. (2004) State-directed development: political power and industrialization in the global periphery. Cambridge: Cambridge University Press.

Kress, G. and Van Leeuwen, T. (1996) Reading Images: the grammar of visual design. London: Routledge. 
Kress, G. (2010) Multimodality - A Social Semiotic Approach to Contemporary

Communication. London: Routledge.

Laqueur, W. (1977) Terrorism. Boston: Little Brown

Larson, F. (2014) Severed: a history of heads lost and heads found. London: Granta Books.

Page, E. (2009) 'Men, masculinity and guns: can we break the link?'. IANSA Women's Network.

Pearlstein, R. (1991). The mind of the political terrorist. Wilmington, DE: Scholarly Resources.

Phillips, P. and Pohl, G. (2014), 'Prospect Theory and Terrorist Choice' Journal of Applied Economics, Vol. 17, pp. 139-160

Phillips, T. (2015) 'China still uses medieval torture against opponents'. The Guardian, $12^{\text {th }}$ November 2015.

Picart, C.J. (2007) Monsters in and Among Us: Toward a Gothic Criminology. Fairleigh Dickinson University Press.

Potter, H. (1993) Hanging in Judgment: religion and the death penalty in England. Canterbury press

Price, H. (1977) 'The strategy and tactics of revolutionary terrorism'. Comparative Studies in Society and History, 19, 52-65.

Ranstorp, M. (2006) Mapping Terrorism Research: State of the Art, Gaps and Future Direction. London: Routledge.

Rapoport, D., 1984. 'Fear and trembling: terrorism in three religious traditions'. American Political Science Review, 78 (3), 658-677.

Rapoport D. C. and Alexander, Y. (1982) The morality of terrorism: religious and secular justifications. New York: Pergamon,

Rastier, F. (1998) 'On signs and texts: cognitive science faces interpretation'. Applied Semiotics/Sémiotique appliquée, 2:5, pp. 195-244.

Reid, E. (1997) 'Evolution of a Body of Knowledge: An Analysis of Terrorism Research' Information Processing and Management, 33(1): 91-106.

Ryan, L. (2014) 'Islam does not change': young people narrating negotiations of religion and identity' Journal of Youth Studies, Vol.17(4), pp.446-460

Schmid, A. and Jongman, A. (1988) Political Terrorism: A New Guide to Actors, Authors, Concepts, Databases, Theories and Literature. Amsterdam: North Holland Publishing Company. 
Shiv, M. (2015) 'The ISIS papers: leaked documents show how ISIS is building its State'. The Guardian, $7^{\text {th }}$ December 2015.

Silke, A. (2004) Research on Terrorism: Trends, Achievements and Failures. London: Frank Cass.

Silke, A. (2008) 'Radicalization Holy Warriors: Exploring the Psychological Processes of Jihadi Radicaization.' European Journal of Criminology 5: 99-123.

Sorel, G. (1999). Reflections on violence. Cambridge: Cambridge University Press.

Stanford University (2016) Mapping Militant Organizations: The Islamic State. Posted at: http://web.stanford.edu/group/mappingmilitants/cgi-bin/groups/view/1\#attacks

Stern, J. (2003) Terror in the Name of God: Why Religious Militants Kill. New York: Harper Collins.

Toros, H. (2008) 'Terrorists, Scholars and Ordinary People: Confronting Terrorism Studies with Field Experiences' Critical Studies on Terrorism, 1(2): 297-92.

Turnbull, S. (2003) Ninja Ad 1460-1650. Leeds: Osprey Publishing.

Van Gennep, A. (1909/2011) Les Rites de Passage. Editions A\&J Picard.

Van Leeuwen, T. "Semiotics and iconography' in Van Leeuwen, T. and Jewitt, C. (2001). The Handbook of Visual Analysis. London: Sage Publications.

Yuval-Davis, N. (1997) Gender and Nation. London: Sage.

Žižek, S. (2009). Violence: Six sideways reflections. London: Profile Books.

Zulaika, J. (2008) 'The Terrorist Subject: Terrorism Studies and the Absent Subjectivity' Critical Studies on Terrorism, 1(1): 27-36. 


\section{Appendix 1: Pictures of Execution.}

These come from screenshots of videos. The main website that divulged them is SITE, a terrorism monitoring group.

Picture 1: James Foley, $19^{\text {th }}$ August 2014

Picture 4: Hervé Gourdel, $24^{\text {th }}$ September

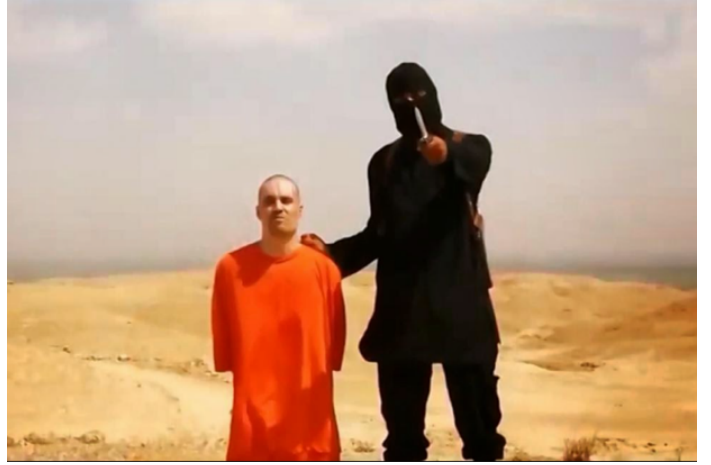

2014

Picture 2: Steven Sotloff, $2^{\text {nd }}$ September 2014
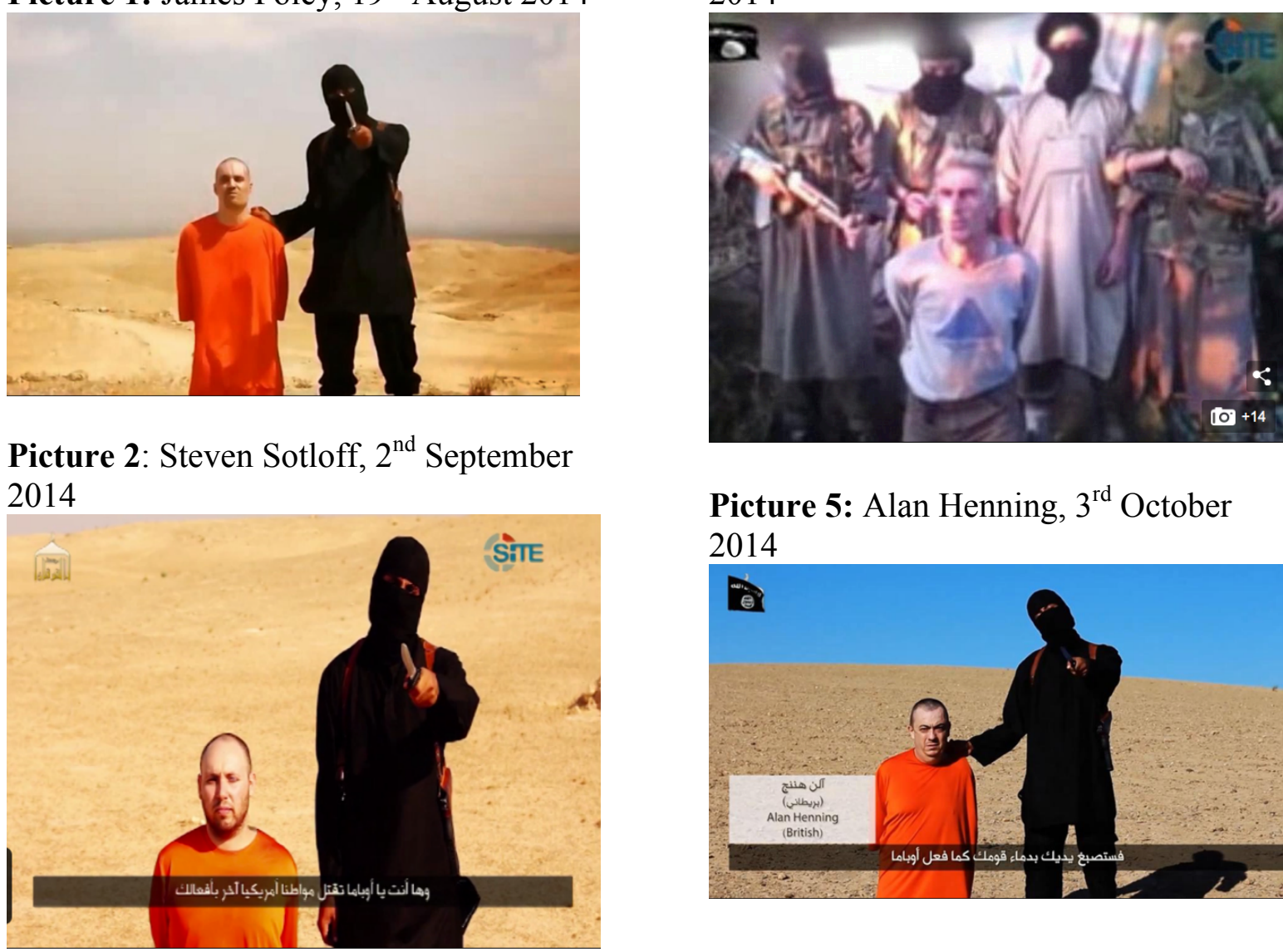

Picture 5: Alan Henning, $3^{\text {rd }}$ October 2014



Picture 3: David Haines, $13^{\text {th }}$ September 2014

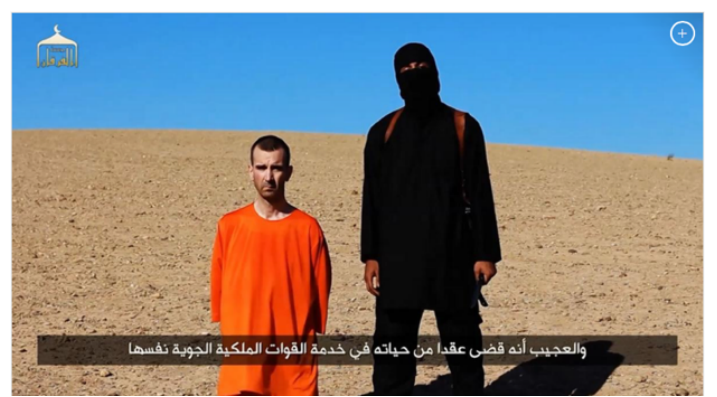




\section{Appendix 2:}

\section{Picture A:}

Jenus di Nazareth, $2^{\text {nd }}$ March 2015. Pillole di Jenus. CMagicpress Edizioni srl.

\section{PILLOLE DI JENUS S}

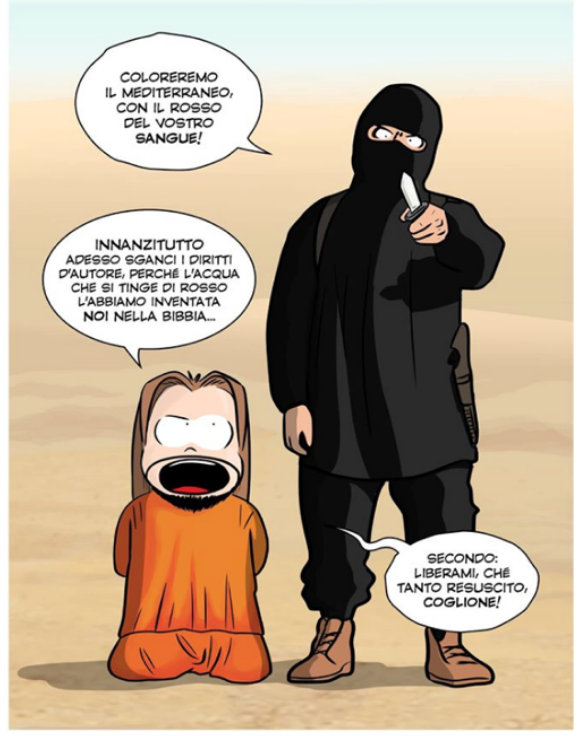

\section{Picture B:}

Utagawa Toyonobu, 1883. A ninja attacking Hydeyoshi's retainers. CHonolulu Museum of Art. Object number: 23992

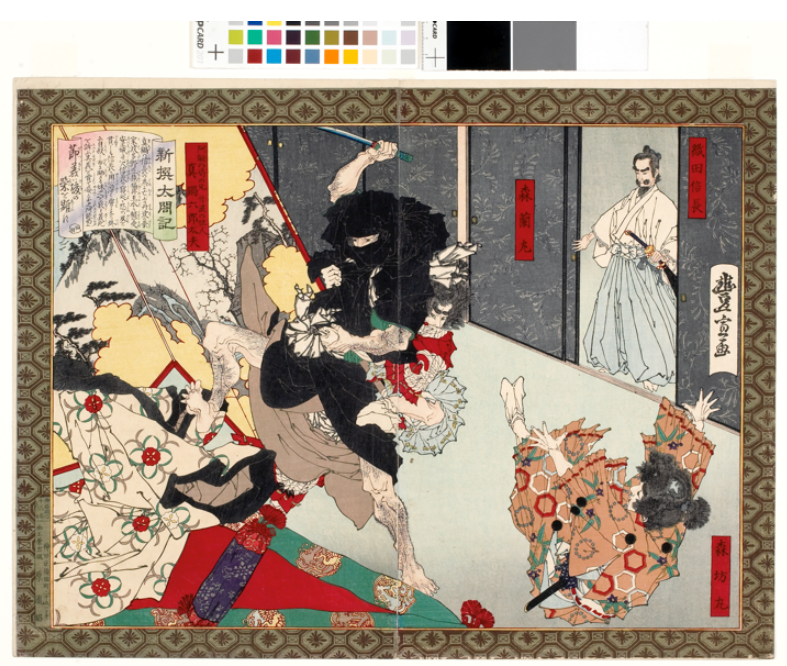




\section{Picture C:}

Utagawa Kunisada, 1852. Ninja about to attack Prince Genji. CPICTURES FROM HISTORY

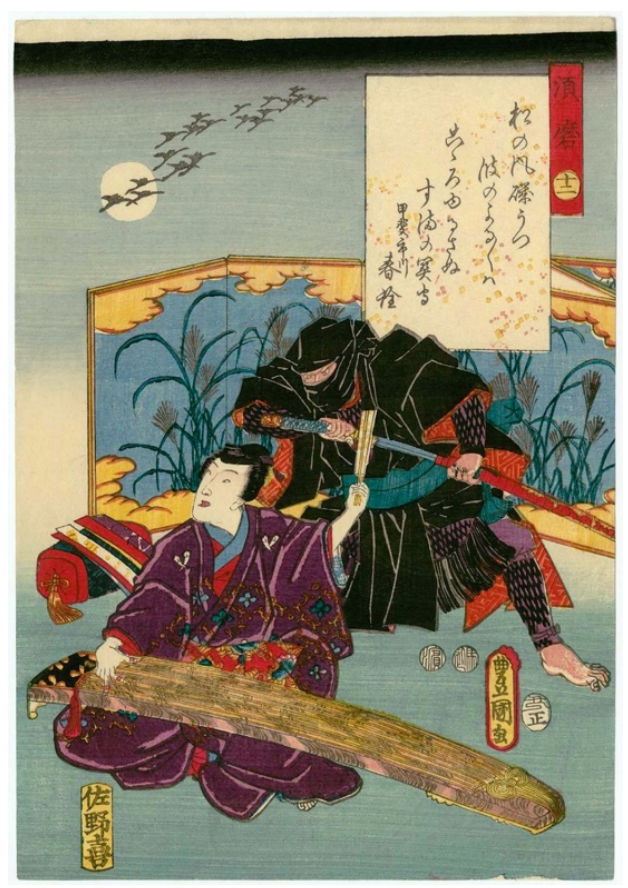

\section{Picture D:}

Giulio Bertoletti, 1943-1944. E tu... cosa fai? [and you... what are you doing?]. (CThe Wolfsonian-Florida International University, The Mitchell Wolfson, Jr. Collection. Accession: XX1990.2248

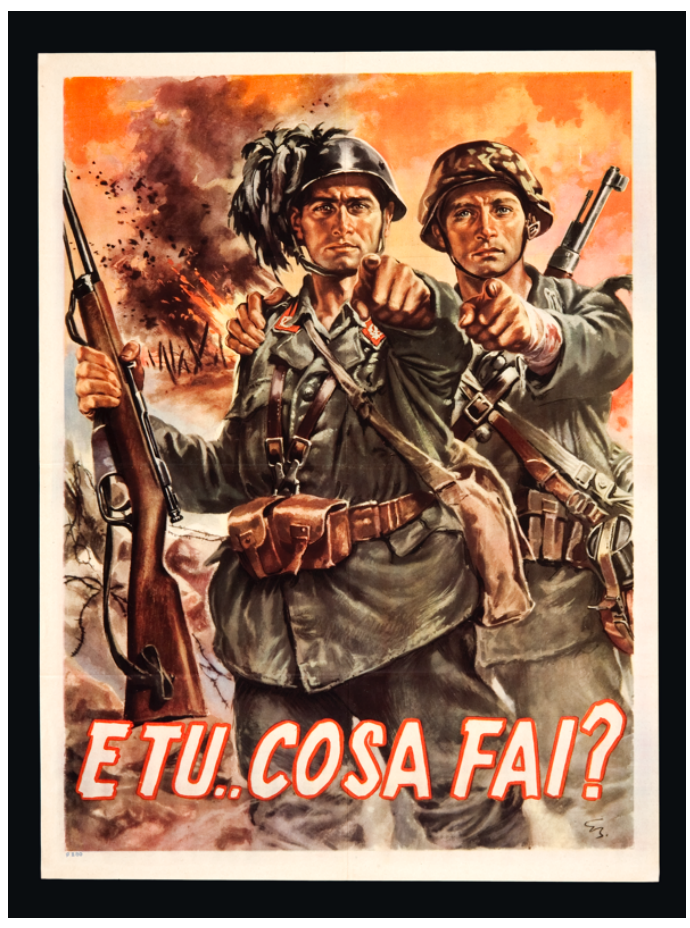




\section{Picture E:}

Dimitrii Moor, 1920. Did you volunteer? CBritish Library Board, Shelf-mark: HS.74/2009(10)

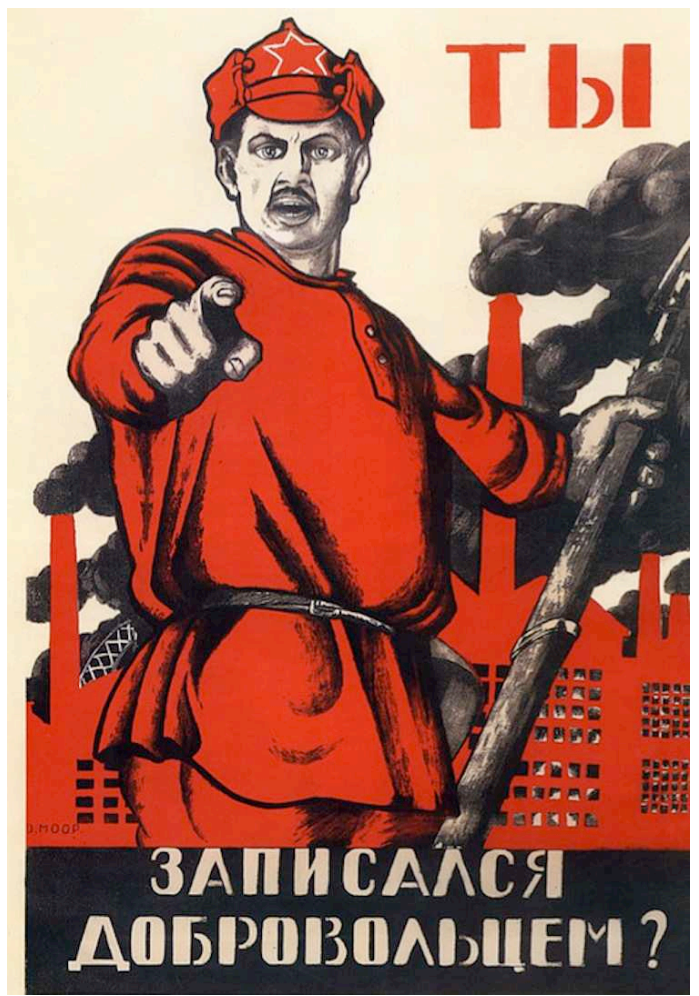

\section{Picture F:}

Decretals of Gregory IX with gloss of Bernard of Parma, c1300-c1340. Detail of a bas-depage. CBritish Library Board, Royal MS 10 E IV, f61v.

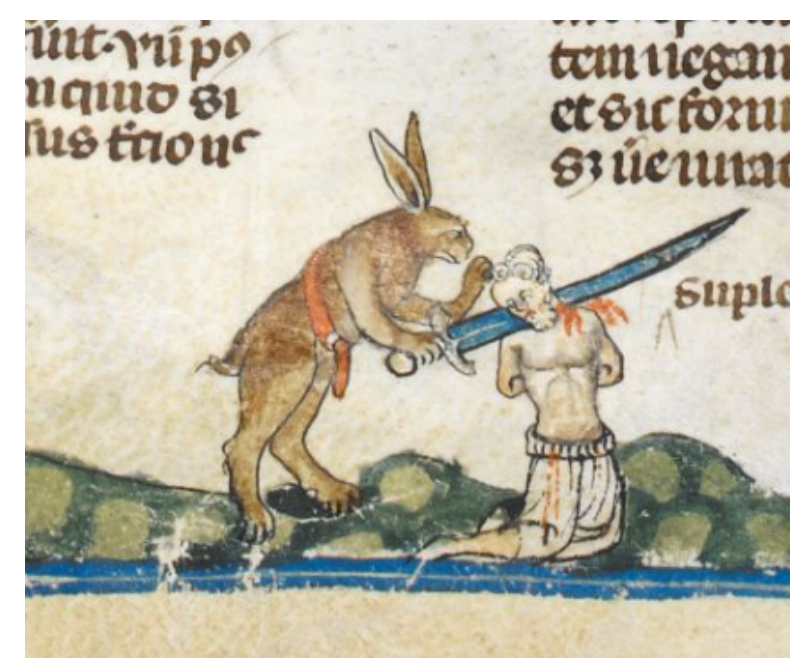




\section{Picture G:}

James Flagg, c1917. I want you for the U.S Army. C Library of Congress prints and photographs. Number: 96507165

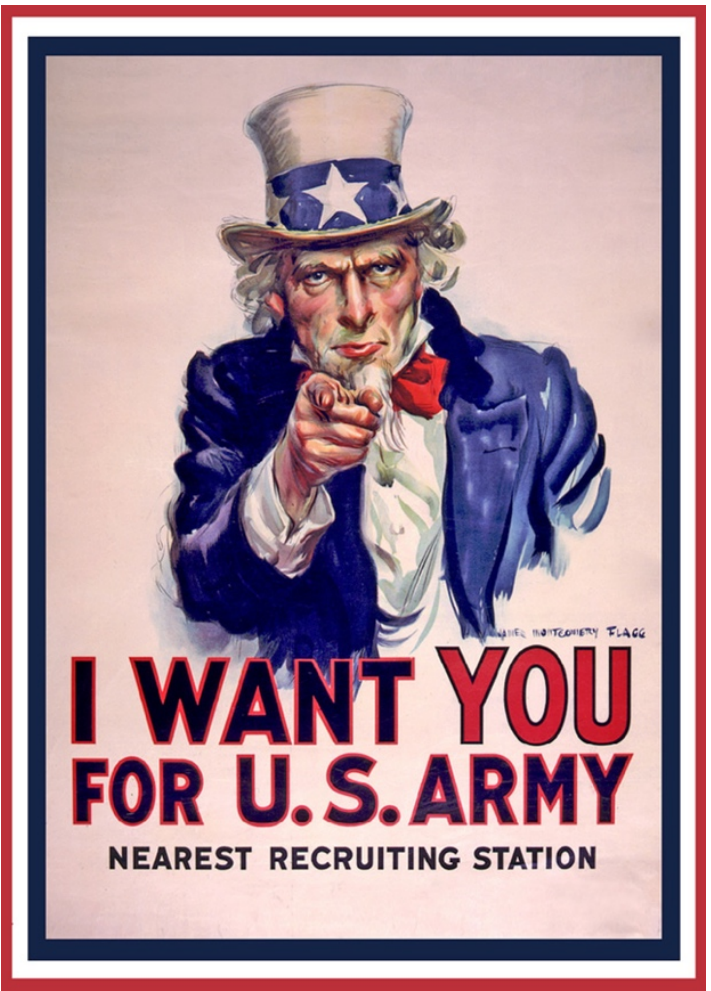

\section{Picture H:}

Who’s absent? 1915. C Imperial War Museums. Art. IWM PTS 0314

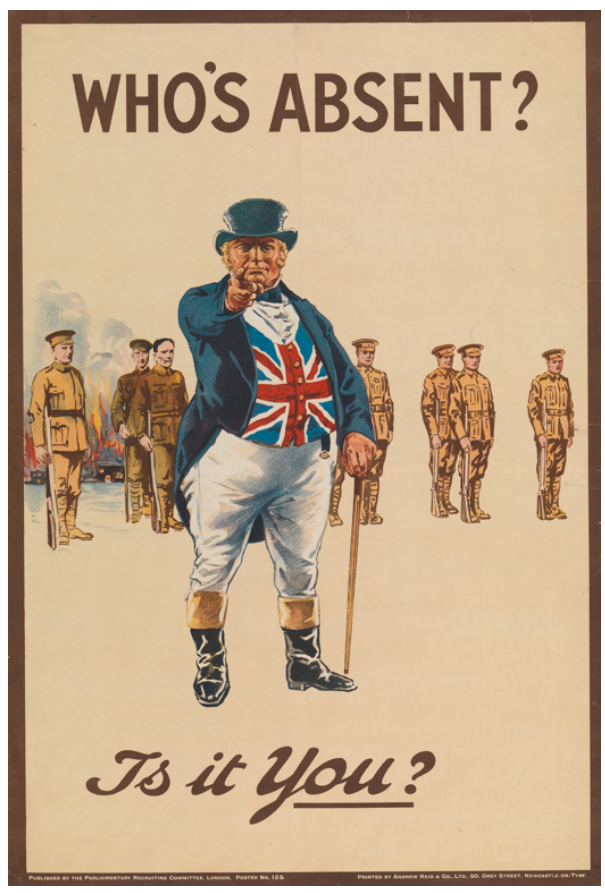

